\title{
Body weight and maximal acid output*
}

\author{
H. G. DesaI \\ M.D.(Bom.)
}

M. P. ZAVERI

B.Sc.(Bom.)

\author{
F. P. Antia \\ M.D.(Bom.), M.S.(Illi.), F.R.C.P.(Lond.) \\ Department of Gastroenterology, BYL Nair Charitable Hospital, \\ Dr A. L. Nair Road, Bombay 8
}

\section{Summary}

Dose-response curves were obtained from forty male control subjects and forty male patients with duodenal ulcer from India on the subcutaneous histamine test.

The body weight and maximal acid output (MAO) showed a positive correlation just significant at the $5 \%$ level in control subjects $(P=0.05)$ but not in patients with duodenal ulcer.

The values of MAO on dose-response curves are comparable in control subjects but are appreciably lower in patients with duodenal ulcer from India compared with those from Britain and North America. However, the values expressed as $\mu \mathrm{Eq} / \mathbf{k g}$ body weight are considerably higher in both groups of subjects from India compared with those from western populations.

DATA showing the relationship of 'maximal' acid output (MAO) to body weight are conflicting. Between these two parameters, no correlation was observed in the augmented histamine test (AHT) (Kay, 1953) in male or female patients with peptic ulcer from Britain and in male control subjects from Britain (Baron, 1964) and India (Vakil \& Mulekar,
1965; Goyal, Gupta \& Chuttani, 1966) but a significant positive correlation was observed in infants (Rodbro, Krasilnikoff \& Christansen, 1967), children (Ghai et al., 1965; Kopel \& Barbero, 1967; Lari, Lister \& Duthie, 1968) and adult female control subjects from Britain (Baron, 1964) and India (Vakil \& Mulekar, 1965) (Table 1). A positive correlation was also observed in rats (Shay, Sun \& Grunenstein, 1954) and dogs (Baron, unpublished data).

The object of this study was to perform doseresponse curves with subcutaneous histamine in male control subjects and patients with duodenal ulcer with a view to estimating MAO accurately in each individual included in the study and to observe its relationship to body weight.

Material and methods

Control subjects and patients

Forty adult male healthy subjects (average age 28.3 years) and forty male patients (average age 36.4 years) with duodenal ulcer (radiologically confirmed) were included in the study.

* Part of the work was supported by a grant from TNMC and BYL Nair Charitable Hospital Research Society.

TABLE 1. Relationship of body weight (BW) and lean body mass (LBM) to acid output

\begin{tabular}{|c|c|c|c|c|c|}
\hline Author and date & Subjects & $\begin{array}{c}\text { Weight } \\
\text { (kg) }\end{array}$ & Method & Correlation & Conclusion \\
\hline $\begin{array}{l}\text { Cox (1952) } \\
\text { Baron (1964) } \\
\text { Vakil \& Mulekar (1965) } \\
\text { Goyal et al. (1966) } \\
\text { Lawrie \& Forrest (1965) } \\
\text { Desai et al. (1969) } \\
\text { Baron (1964) } \\
\text { Vakil \& Mulekar (1965) } \\
\text { Ghai et al. (1965) } \\
\text { Rodbro et al. (1967) } \\
\text { Hume \& Melrose (1967) } \\
\text { Baron (1969) }\end{array}$ & $\begin{array}{l}\text { Peptic ulcer } \\
\text { Control males } \\
\text { DU males } \\
\text { Control males } \\
\text { Control males } \\
\text { DU males } \\
\text { Control males } \\
\text { Control males } \\
\text { Control females } \\
\text { Control females } \\
\text { Children } \\
\text { Infants } \\
\text { Control (M+F) } \\
\text { DU (M+F) } \\
\text { Control males } \\
\text { Control females }\end{array}$ & $\begin{array}{l}-\overline{67 \cdot 9} \\
70 \cdot 0 \\
50 \cdot 6 \\
62 \cdot 9 \\
57 \cdot 9 \\
- \\
51 \cdot 9 \\
68 \cdot 4 \\
50 \cdot 6 \\
25 \cdot 3 \\
11 \cdot 3 \\
- \\
- \\
67 \cdot 9 \\
58 \cdot 4\end{array}$ & $\begin{array}{l}\text { Autopsy } \\
\text { AHT } \\
\text { AHT } \\
\text { AHT } \\
\text { AHT } \\
\text { AHT } \\
\text { IHT* } \\
\text { IHT† } \\
\text { AHT } \\
\text { AHT } \\
\text { AHT } \\
\text { AHT } \\
\text { AHT } \\
\text { AHT } \\
\text { AHT } \\
\text { AHT }\end{array}$ & $\begin{array}{l}\text { BW and PCM } \\
\text { BW and PAO } \\
\text { BW and PAO } \\
\text { BW and MAO } \\
\text { BW and MAO } \\
\text { BW and MAO } \\
\text { BW and PAO } \\
\text { BW and PAO } \\
\text { BW and PAO } \\
\text { BW and MAO } \\
\text { BW and MAO } \\
\text { BW and MAO } \\
\text { LBM and MAO } \\
\text { LBM and MAO } \\
\text { LBM and MAO } \\
\text { LBM and MAO }\end{array}$ & $\begin{array}{l}\text { No } \\
\text { No } \\
\text { No } \\
\text { No } \\
\text { No } \\
\text { No } \\
\text { No } \\
\text { No } \\
\text { Yes } \\
\text { Yes } \\
\text { Yes } \\
\text { Yes } \\
\text { Yes } \\
\text { Yes } \\
\text { Yes } \\
\text { Yes }\end{array}$ \\
\hline
\end{tabular}

MAO, Maximal acid output; PAO, peak acid output. 


\section{Method}

Subcutaneous histamine tests (SHT) were performed as described in a previous study (Desai, Zaveri \& Antia, 1970). MAO (0-60 min) was calculated by method of Card \& Marks (1960).

Thirty-nine control subjects and thirty-six patients with duodenal ulcer received doses of $1 \cdot 6,2 \cdot 0,2 \cdot 4$, $2.8,3.2 \mathrm{mg}$ histamine acid phosphate (HAP) subcutaneously on different days and one control subject and four patients with duodenal ulcer included from a previous study (Desai, Borkar \& Jeejeebhoy, 1967) received 40,50,60 $\mu \mathrm{g} / \mathrm{kg}$ body weight doses of HAP. Six control subjects (with the minimal value of HAP of $1.6 \mathrm{mg}$ for MAO) also received a 1.2-mg dose of HAP.

\section{Results}

\section{Body weight and maximal acid output}

Control subjects. The mean and standard deviation (SD) of body weight and MAO were $47 \cdot 6 \pm 9 \cdot 17 \mathrm{~kg}$ and $20.7 \pm 7.22 \mathrm{mEq} / \mathrm{hr}$ respectively. A positive correlation between these two parameters was just significant at $5 \%$ level (Fig. 1; $r=+0.31, P=0.05$ ). The mean and SD of the value of acid output expressed as $\mu \mathrm{Eq} / \mathrm{kg}$ body weight $/ \mathrm{hr}$ was $441.0 \pm$ 148.9 .

Patients with duodenal ulcer. The mean and SD of body weight and MAO were $47.0 \pm 8.79 \mathrm{~kg}$ and $30.06 \pm 10.04 \mathrm{mEq} / \mathrm{hr}$ respectively. No correlation was observed between these parameters (Fig. 1; $r=0.05, P>0.05)$. The mean and SD of the value of acid output expressed as $\mu \mathrm{Eq} / \mathrm{kg}$ body weight $/ \mathrm{hr}$ was $658 \cdot 5 \pm 235 \cdot 8$.

The average values of MAO in control subjects $(20.7 \pm 7.22 \mathrm{mEq} / \mathrm{hr})$ and patients with duodenal ulcer $(30.06 \pm 10.04 \mathrm{mEq} / \mathrm{hr})$ showed significant differences $(P<0.01)$ and the values expressed as $\mu \mathrm{Eq} / \mathrm{kg}$ body weight $/ \mathrm{hr}$ were also significantly different in these two groups $(P<0.01)$.

Body weight and minimal dose of histamine (independent of, or in relation to body weight) for MAO

Control subjects. A significant positive correlation was observed between body weight and the minimal dose of HAP, independent of body weight, for MAO (Fig. 2; $r=+0.43, P<0.01$ ) and a significant negative correlation was observed between the body weight and the minimal dose of HAP, in relation to body weight, for MAO (Fig. 3, $r=-0.35, P<0.05$ ) i.e. greater the weight of the subject, higher the 'absolute' dose and smaller the dose of HAP, in relation to body weight, for stimulating MAO.

Patients with duodenal ulcer. No correlation was observed between the body weight and the minimal dose of HAP, independent of body weight, for MAO (Fig. 2; $r=+0.08, P>0.05$ ) but a highly significant negative correlation was observed between the body weight and the minimal dose of HAP, in relation to body weight, for MAO (Fig. 3; $r=-0.75, P<$ 0.001).

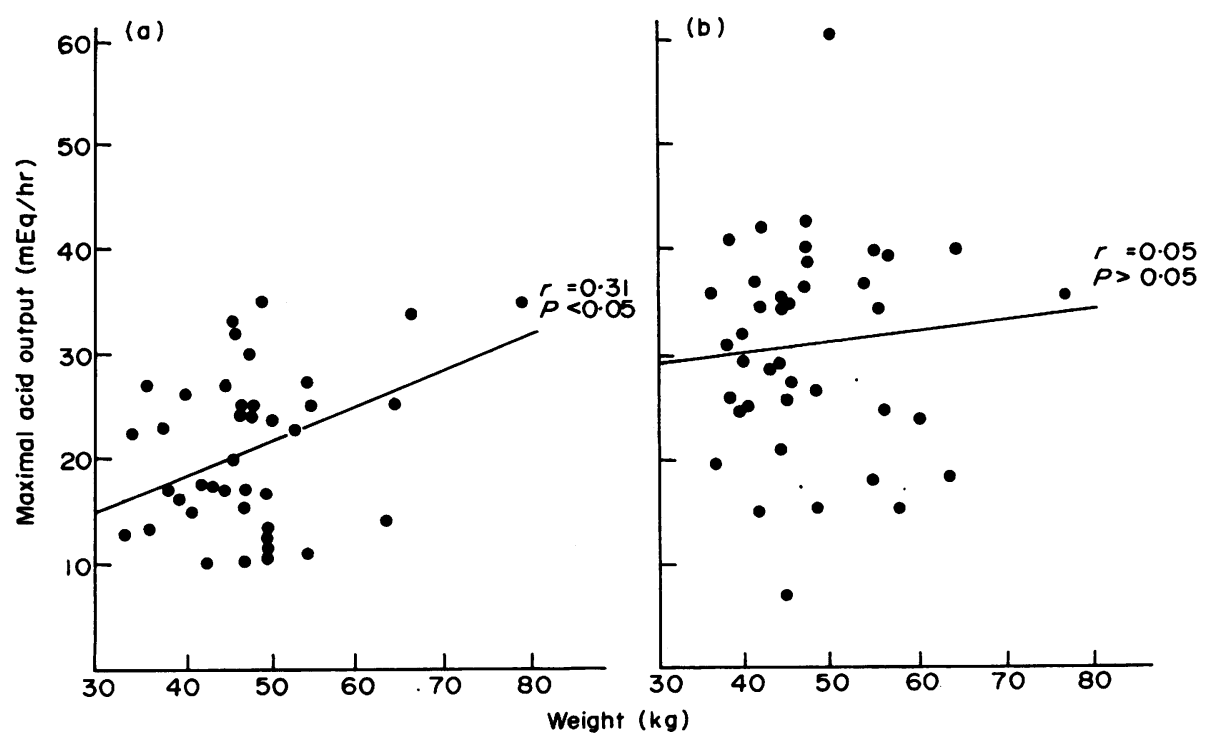

FIG. 1. Correlation between the body weight and the maximal acid output in (a) control subjects and (b) patients with duodenal ulcer. 


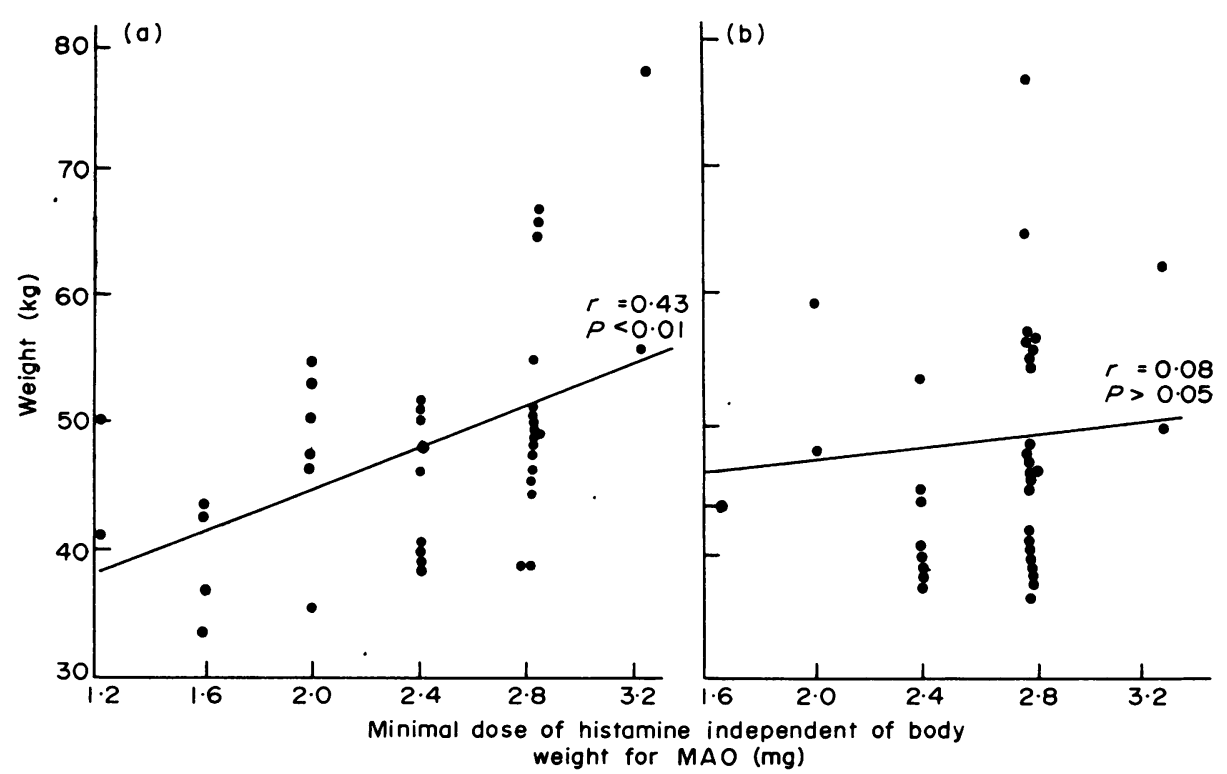

FIG. 2. Correlation between the body weight and the minimal dose of HAP, independent of body weight, for MAO in (a) control subjects and (b) patients with duodenal ulcer.

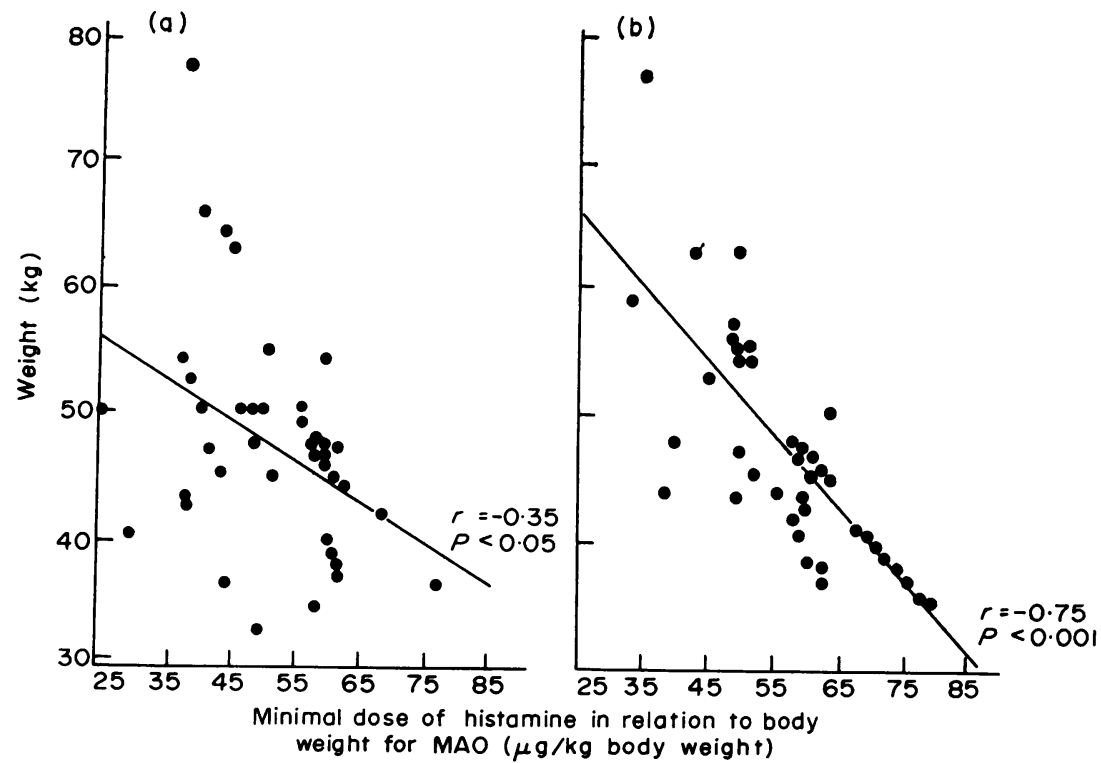

Fig. 3. Correlation between the body weight and the minimal dose of HAP, in relation to body weight, for MAO in (a) control subjects and (b) patients with duodenal ulcer.

\section{Discussion}

The relationship between body weight (or lean body mass, LBM) and MAO on SHT has been reported in soveral studies (Table 1). The difficulty of estimating MAO accurately in all individuals with
$0.04 \mathrm{mg} / \mathrm{kg}$ body weight of HAP was recently emphasized (Desai, 1969; Stempien, 1970) as subjects weighing less than $60 \mathrm{~kg}$ receive a submaximal stimulus (Desai, Borkar \& Jeejeebhoy, 1967a) whilo those weighing $80 \mathrm{~kg}$ or more may perhaps receive a 
supramaximal stimulus causing a partial reduction of acid output (Desai et al., 1969). In the present study, dose-response curves were hence performed to obtain MAO accurately in each individual. The body weight and the MAO showed a positive correlation in male control subjects which was just significant at $5 \%$ level $(r=+0.31, P=0.05)$ while no correlation was observed in patients with duodenal ulcer $(r=$ 0.05, $P>0.05$ ).

In the present study, the average value of MAO $(20.7 \mathrm{mEq} / \mathrm{hr})$ is appreciably higher than that reported $(10 \cdot 1,12 \cdot 0,12 \cdot 2,16 \cdot 9,17 \cdot 0)$ on AHT in studies from India (Raju et al., 1963; Kedarnath \& Garg, 1965; Vakil \& Mulekar, 1965; Cowan, Joseph \& Satija, 1966; Madangopalan, Subramaniam \& Saroja, 1967). This value is comparable with that reported $(22 \cdot 4,22 \cdot 3,17 \cdot 1,23 \cdot 2 \mathrm{mEq} / \mathrm{hr})$ on AHT for subjects from Britain and North America (Kay, 1953; Bruce et al., 1959; Marks \& Shay, 1959; Baron, 1963a). However, the average value of acid output expressed as $\mu \mathrm{Eq} / \mathrm{kg}$ body weight $/ \mathrm{hr}(441)$ in our control subjects is higher than that reported (317) for subjects from Britain (Baron, 1969) due to the lower average body weight of Indian subjects. The average value of MAO $(30.06 \mathrm{mEq} / \mathrm{hr})$ in our male patients with duodenal ulcer from Bombay is considerably higher than that reported $(17 \cdot 9,20 \cdot 1$, $25 \cdot 0,26.0)$ on AHT in studies from India (Raju et al., 1963; Kedarnath \& Garg 1965; Vakil \& Mulekar, 1965; Cowan et al., 1966; Madangopalan et al., 1967). However, this value is still considerably lower than that reported $(37 \cdot 5,37 \cdot 0,34 \cdot 2,39.6 \mathrm{mEq} / \mathrm{hr})$ on AHT for subjects from Britain and America (Kay, 1953; Bruce et al., 1959; Marks \& Shay, 1959; Baron, $1963 \mathrm{~b}$ ). In contrast, the value of acid output expressed as $\mu \mathrm{Eq} / \mathrm{kg}$ body weight $/ \mathrm{hr}(658.5)$ in our male patients with duodenal ulcer is considerably higher than that reported $(608 \cdot 2)$ for patients from Britain (Baron, 1969). The differences in values of $\mu \mathrm{Eq} / \mathrm{kg}$ body weight $/ \mathrm{hr}$ in control subjects and patients with duodenal ulcer from India and Britain are in fact greater than indicated by these figures as the values of acid output were obtained from MAO (0-60 min) in the present study and from peak acid output (two highest consecutive 15 -min values) in the study from Britain.

\section{References}

Baron, J.H. (1963a) Studies of basal and peak acid output with an augmented histamine test. Gut, 4, 136.

BARON, J.H. (1963b) An assessment of the augmented histamine test in the diagnosis of peptic ulcer. Gut, 4, 243.

Baron, J.H. (1964) Peptic ulcer, gastric secretion and bodybuild. Gut, 5,83 .

BARON, J.H. (1969) Lean bodymass, gastric acid and peptic ulcer. Gut, 10, 637.

Bruce, J., CARD, W.I., Marks, I.N. \& Sircus, W. (1959) The rationale of selective surgery in the treatment of duodenal ulcer. Journal of the Royal College of Surgeons of Edinburgh, 4, 85.

CARD, W.I. \& MARKs, I.N. (1960) The relationship between the acid output of the stomach following 'maximal' histamine stimulation and the parietal cell mass. Clinical Science, 19, 147.

Cowan, B., Joseph, A. \& SatiJa, V.K. (1966) The gastric mucosa in anaemia in Punjabis. Gut, 7, 234.

Cox, A.J. (1952) Stomach size and its relation to chronic peptic ulcer. Archives of Pathology, 54, 407.

DESAI, H.G. (1969) Factors affecting maximal acid secretion. Postgraduate Medical Journal, 45, 272.

Desai, H.G., Antia, F.P., Gupte, U.V. \& Potnis, P.R. (1969) Dose of histamine for maximal stimulation of gastric acid secretion. Modified subcutaneous histamine test. Gastroenterology, 57, 636.

Desai, H.G., Borkar, A.V. \& Jeejeebhoy, K.N. (1967a) Dose-weight relationship of histamine for maximal stimulation of gastric acid secretion. Gastroenterology, 53, 71.

Desai, H.G., Borkar, A.V. \& Jeejeebhoy, K.N. (1967b) Histamine-infusion test. Part 1, control subject. Indian Journal of Medical Science, 21, 785.

Desai, H.G., Zaveri, M.P. \& Antia, F.P. (1970) Comparison of dose-response curves with subcutaneous and intravenous histamine. Gastroenterology, 59, 701.

Ghai, O.P., Singh, M., Walia, B.N.S. \& GhadeKar, N.G. (1965) An assessment of gastric acid secretory response with 'maximal' augmented histamine stimulation in children with peptic ulcer. Archives of Diseases of Childhood, 40, 77.

Goyal, R.K., Gupta, P.S. \& Chuttani, H.K. (1966) Gastric acid secretion in Indians with particular reference to the ratio of basal to maximal acid output. Gut, 7, 619 .

Hume, R. \& Melrose, A.G. (1967) Relation between maximal acid output of stomach and lean body mass. British Medical Journal, 2, 30.

KAY, A.W. (1953) Effect of large doses of histamine on gastric secretion of $\mathrm{HCl}$-an augmented histamine test. British Medical Journal, 2, 77.

Kedarnath, Paul D. \& Garg, K.C. (1965) Augmented histamine test in peptic ulcer and ulcer dyspepsia. Journal of the Association of Physicians of India, 13, 627.

KoPEL, F.B. \& BARBERo, G.J. (1967) Gastric acid secretion in infancy and childhood. Gastroenterology, 52, 1101.

LARI, J., Lister, J. \& Duthie, H.L. (1968) Response to gastric pentapeptide in children. Journal of Pediatric Surgery, 3, 682.

LAWRIE, J.H. \& ForRest, A.P.M. (1965) The measurement of gastric acid. Postgraduate Medical Journal, 41, 408.

Madangopalan, N., Subramaniam, R. \& Saroja, R. (1967) Report on augmented histamine test from Madras. Journal of the Association of Physicians of India, 15, 501.

MARKS, I.N. \& SHAY, H. (1959) Observations in the pathogenesis of gastric ulcer. Lancet, i, 1107.

Raju, S., Ganguly, P.C., Bhat, H.S. \& Nariel wala, F.M. (1963) The place of augmented histamine test as a study of gastric acid secretion based on 120 duodenal ulcer patients and 40 controls. Journal of the Association of Physicians of India, 13, 399.

Rodbro, P., Krasilnikoff, P.A. \& Christiansen, P.M. (1967) Parietal cell secretory function in early childhood. Scandinavian Journal of Gastroenterology, 2, 209.

Shay, H., Sun, D.C.H. \& Grunenstein, M. (1954) A quantitative method for measuring spontaneous gastric secretion in the rat. Gastroenterology, 26, 906.

Stempien, S.J. (1970) Critique of tests of maximal gastric acid secretion including insulin. Gastroenterology, 58, 597.

VAKIL, B.J. \& Mulekar, A.M. (1965) Studies with the maximal histamine test. Gut, 6, 364. 